\title{
Virtual Social Networks for Cooperative Learning: an EduCamp Experience
}

\author{
Adrian Schroeder Esquivel Guemes and Pedro José Canto Herrera \\ Autonomous University of Yucatán, México
}

\begin{abstract}
Virtual Social Networks have increasingly become integrated into the lives of college students, as means of communication and recreation. Because of this, their mastery of these technologies has the potential to be used as a tool for the acquisition of other skills, as demonstrated by the EduCamp workshop designed by the University of Buenos Aires: a knowledge sharing activity in which participants learned from each other. This research project had the objective of replicating this workshop with the Faculty of Education students of the Autonomous University of Yucatán, to determine if their knowledge of the use of virtual social networks could be used for the digital learning of other web 2.0 technologies. Results were positive, with participants acquiring skills related to the use of cloud-based services and web based reference and citation tools.
\end{abstract}

\section{Introduction}

\subsection{Theory}

Prensky proposes the term "digital natives" to refer to the first generation which has grown surrounded by technological communication systems, and for whom the use of the internet and cellphones are part of their daily lives [1]. In contrast, those who were born before the digital age and have had to adjust to it are referred to as "digital immigrants". Studies like those of Kennedy, Krause, Judd, Churchward \& Gray and Kravik, Caruso \& Morgan point the different ways in which digital natives adopt Web 2.0 technologies to their social, academic and entertainment needs [2] [3]. One of these technologies is that of Virtual Social Networks, social interaction sites which are defined by Vidal, Vialart and Hernández, as a: "constitute and open system, in permanent construction, which involves people that identify with the same needs and issues, and whose principles are creation, sharing and collaboration" [4]. Among the most used by college students, as seen in Parra`s study, are Facebook, Twitter, MySpace, FotoLog and Hi5. Being possible to use them from any computer with Internet access, along with their constant integration of applications for which specific software was necessary before instant messaging, video calls, and file sharingVirtual Social Networks are each day a more important part of cyberspace [5]. On this matter, Santana points out that: "their transcendence can be seen on the fact that their use has greatly surpassed that of e-mail and have positioned themselves on the Web over searches for common interests websites" [6].

Originally designed with the purpose of facilitating the creation of social links between individuals with similar interests, these have started with time to be used with more diverse purposes , among them the educational. Abarca points out that: "social networks have come to take a heavy role at home and on the daily lives of common society" [7]. This ever growing integration of social networks onto communications have produced a need to use them, not only for entertainment, leisure and social link reinforcement, but as a pedagogic and communication method for teachers on all educational levels, and specially on college". However, according to Torre, huge quantities of school-age youths only use them to maintain communication with their friends, colleagues and family, leaving aside their utility as a mean of access to academic information, formative processes support and for the production of multimedia materials such as texts, graphics or videos [8]. It's because of this popularity that many efforts have been made to include these sites onto the educational landscape:

Piscitelli, Adaime and Binder recount two examples: in 2009, the University of Buenos Aires put into motion a series of workshops under the name "Project Facebook" [9]. This were made as a "collaborative and open educational system, adjusted to the ways by which knowledge is produced, distanced from educational tradition which conceives students as receivers and not as actors in these processes". Also, in 2007 the University of Colombia, executed a series of collective learning activities using social networking tools. Under the "EduCamp" name, these consisted of a knowledge sharing process in which each participant interacted directly with others, without the need of an "expert" workshop manager. Alarcón and Lorenzo make note that the term Web 2.0 or Social Web is used "to refer to a new tendency in Web design and use, in which the user es the center of the information and where he also acts as an active creator of content" [10].

This paradigm shift, in which the content creation capacity went from being in the hands of a niche of specialised groups to being of public domain, and led 
to the creation of one of the most actually used systems by school-age youths for the interchange of information: the Virtual Social Networks. These are defined by Lorenzo-Romero, Gómez-Borja and Alarcón-del-Amo as those Web services by way of which it is possible for users to: "make a public or semi-public profile on a delimited system, articulate a list of other users to establish a connection with, and to see and move through their connections list and those of other users inside the same system" [11]. As a result, there has been a radical change in the way information is transmitted, going from a vertical model to an horizontal one, in which it is freely shared in multiple directions.

Pineda, Meneses and Telles comment that: "in traditional communication, the involved actors in information exchanges assumed passive roles; while in the frame of Web communications, there are no passive subjects, as the generated dynamics establish reticular relations" [12]. This change opens new opportunities for the improvement of formative academic processes, serving as knowledge transmission facilitators and increasing the quantity of channels in which to establish teacher-student communication processes, which used to be limited to face-to-face interaction in the classroom". As Torres-Díaz, Dunia and Valdiviezo point out: "Virtual Social Networks permit the consolidation of contributions and generated information, giving place to new learning forms based on the exchange of messages and content between users; whose working processes differ from the traditional didactic that is applied on many virtual learning environments [13]. It is then a priority to establish formal changes in curriculum development for the inclusion of these technologies, based on their possibilities for the reinforcement of teacher-student relationships, both inside and out of the classroom, and to ease shared academic work by eliminating the difficulty of doing it face-to-face outside of class time, where many times it is hard for the student to point their questions to the teacher".

Duart makes emphasis on the need to make this paradigm change, seeing that: "true transformation is found in academic dynamics, in the educative process that is done in and outside of it today [14]. The active and social use of the Web cannot be ignored in teaching plans anymore. Even if somebody -mistakenly- center teaching on the transmission of knowledge, it not possible to do so today in just an unidirectional way". However, this change does not imply the disappearance of the professor in the teaching process, but a reworking of the manner in which he interacts with his students, making a transition from a knowledge provider to that of a moderator or facilitator for accessing it. Martínez, Corzana and Millán observe about this issue that, even if the learning process in a Virtual Social Network takes form in a much more horizontal way that in other technologies, the purpose of the teacher continues to be of great importance, serving as a guide who secures that the generated knowledge is correct and of an adequate level for the course, as well as an evaluator of the generated activities [15].

The benefits of using Virtual Social Networks are not limited to the acquisition of knowledge related to the particular course in attendance, but instead allow the development of diverse communication and group working abilities that result transversal and transferable to other formative areas. Stornaiuolo, Dizio and Hellmich comment on this that: "the use of Virtual Social Networks in education can be a generative method to encourage important communication skills, because they focus on the collaborative creation of knowledge using diverse semiotic instruments" [16]. It is imperative then to make a transition from the classic concept of learning as a single direction process in which the professor transmits information to the student, towards one that understands it as the result of the participation of all involved subjects, who in turn become both receivers and transmitters of knowledge.

Pineda, Meneses and Téllez suggest that: "collective intelligence as a goal of Virtual Social Networks in learning communities needs to overcome the traditional focus on individual intelligence, in order to reinforce competition skills and spirit". Also discussing this issue, Satori, as cited by Aguilar and Said, notes that "the reception processes around digitalisation need to know how the new social pedagogic mechanisms and strategies are received, cultured and established by the bit generation" [17]. In a study by Esquivel it was found that, while efforts have been done to transfer formative processes to virtual environments, these have been sometimes limited to their integration on Learning Management Systems (LMS) such as Moodle or Dokeos, in which contents need to be supervised by an administrator, usually the professor of the course in question, who has just placed his classroom materials to be available online, without adapting it to the possibilities of this new medium [18]. When this happens, students are found to be unwilling to incorporate them into their activities, considering that they are not more useful than those they already have done in class; in some ways, they find these services foreign to their reality, while the opposite happens in the case of school materials uploaded to Virtual Social Networks. Alonso and Muñoz de Luna, as cited by Gómez, Roses and Farías comment about this: "the use of Virtual Social Networks, blogs and video applications involve (...) taking information and knowledge to places students associate with entertainment, and where it is possible for them to get closer with less prejudice" [19]. 


\subsection{Purpose}

The purpose of this study is to determine, using an analysis of the results of an online survey about the learnings obtained by a group of students of the Faculty of Education during the application of a workshop under a modification of the EduCamp model, about the way they use the domain they possess of Virtual Social Networks as tools for their digital alphabetisation in the use of other Web 2.0 technologies, with the purpose of identifying methodological adjustments necessary for the acquisition of similarly positive results as those obtained by Piscitelli, Adaime and Binder on 2010.

\subsection{Justification}

Virtual Social Networks have been successfully used in foreign institutions as an addition to classroom work. For this to happen, it was necessary to do various exploration studies, along with the adjustment of contents and the development of work plans which made use of these technologies. These workshops and courses have made it possible for virtual social networks to be used for the digital skill`s development of large quantities of students. However, in México there are very different conditions that arise difficulties for the development of courses like these.

\subsection{Context}

The Faculty of Education is part of the Autonomous University of Yucatán, a middle, grade and post-grade level education public institution, whose mission is the educate professors and educational researchers. One of the grade level programs offered there is the Degree on Education. With an average duration of eight semesters, courses are dividen in obligatory, optative and open subjects, with focus on three complementary formative areas: educational administration, educational orientation and curriculum instruction. On the post-grade level, the Master in Educational Research is offered, with a flexible duration of four semesters, based on a credits system, in which 125, 100 coming from courses and 25 from the elaboration of a thesis, are needed to graduate; students are assigned to one of three areas of specialisation: curriculum instruction, educational policy and educational psychology, as well as on the transversal axis of ethics in educational research, internationalisation and globalisation, and innovation and use of new information and communication technologies. Both are offered in the installations of the Faculty of Education, located on the Social and Anthropological Sciences Campus, with support of a
Learning Management System for external activities [18].

\section{Research method}

\subsection{Design}

This study took place under an investigationaction design, during a workshop session adapted from the EduCamp model of the University of Colombia. During this workshop, a participant observation and online survey took place, and the results derived from data analysis were presented in the form of an investigation report.

\subsection{Instrument}

The used instrument, an online survey designed with the Forms application -available in the Google Drive work suite- consisted of five open answer questions, corresponding to opinions about the activities and knowledge adquiere during the workshop; for validation, a pilot test took place during the first workshop session, taking note of observations as a basis for survey modifications. The final questions were: What did you learn during the workshop? What would you have liked to learn, but could not? What immediate action do you plan to do with your newfound knowledge? What organisation aspects of the workshop could be improved? And what is your opinion about the realised activities?. Results were compiled automatically by the used software, and gathered in a .CSV archive.

\subsection{Data gathering process}

Data gathering was done during the workshop, using an online survey, along with direct observation by the researcher, video recordings and photographies; the participants were students from both the grade and post-grade levels on the Faculty of Education of the Autonomous University of Yucatán, who accepted voluntarily to participate on the project, without linking it to their grades in any form, it is important to point out that each participant was given a package of four books from different academic areas, as was advertised on the invitation to the workshop, as well as a certificate of participation. Two groups were established: one consisted of students from the first semester of the Degree in Education (nine persons), while the second group involved students from all the semesters of the Master in Educational Research (sixteen persons): the first group took part in a workshop session on August the 29th of 2014, while the second group's activities took place on September the 5th of 2014, using a modified session plan, derived from the observation of which activities needed fine tuning in 
form or time management, along with the recommendations of the participants on the first workshop group, taken from the end of session survey.

The workshop, promoted as Virtual Social Networks for Digital alphabetisation, took place on the Homework Room of the previous Faculty of Education building, which had twenty four computers with Internet access, along with an extra one for the use of a professor, linked to a projector and a digital whiteboard. After receiving welcome words and a short introduction to the workshop contents, each student was given a set of sticky tags in which they were asked to write their name in big letters who could be easily seen at a distance, and put them on their clothes to serve as an identifier and proceed to introduce themselves to the rest of the group. After that the researcher projected a series of slides in which it was explained the difference between Virtual Social Networks, Learning Management Systems and Web 2.0 tools, in which their main differences were pointed out along with the principal characteristics of the most popular ones, formation that was also given to the participants by way of a printed list.

After this an example of a Personal Learning Environment, focused on skills for the use of online digital tools, with the purpose of serving as a template so the students could make their own, helping them to identify which Web tools they knew how to use correctly and which abilities they wanted to learn, based on the professional and academic necessities. Workshop rules were given: each student wrote on their tags which Virtual Social Networks, Learning Management Systems and Web 2.0 Tools they knew how to use, and then proceeds to search those students whose tags identified them as having knowledge of tools of their interest, with the purpose of asking them for an introductory lesson about their use, help on how to create an account on the service if necessary, and finally to interchange social profiles if possible; once this was done, they were asked to add the name of the learned tool to their tags, in order to move on to learn another one or teach it in turn -or another one they had domain of- if asked to by another student, establishing a cycle.

After half an hour of this activity, student s were signed to small groups in order to discuss about how these sites and application could be used to improve academic work of both students and professors, with one of the participants from each group appointed to take notes of the discussion to help the group share their conclusions to the other ones in the form of an spoken summary. As closing activity, participants were asked to answer an online survey to gather their opinions about the workshop, for this, the researcher took place in front of the whole group and, using the projector, explained the procedure to follow: students double-clicked over an icon on the computer virtual desktop which linked to a Web site in which the survey was put up, which they were asked to answer individually following the instructions that appeared on the screen; each student answered the survey from their assigned computer, these being distributed in separated rows, with the researcher standing in from of them, unable to see what the students were typing.

\subsection{Data analysis process}

Gibbs's generic model was used, which consists of descriptive codification of recollected data, for posterior categorisation in a way that permits an analytic interpretation of their contents using techniques such as inference and category interpolation [20]. As a first step, answers were transcribed, taking information directly from the automatically compiled database, following Gibbs's recommendation to not edit participations, as valuable data related to expression and language use can be lost. Gibbs also suggests for working with digital archives that: "e-mail, chats, Web pages, blogs and related data imply that other people have already typed the information. However, it is possible that you will need to do some quantity of processing to transform the data for a correct analysis in accord to your research design". After this, a codification of the obtained data was done, with the purpose of establishing relationships between the recollected answers.

Gibbs defines the codification process as: "the way in which you define what do the analysed data refer to. This implicates identifying and registering one or more texts or other kind of data as part of a chart that, in some sense, give examples of the same descriptive or theoretical idea. Commonly, various texts are identified and linked under the same name for that idea: a code. This way, any text that refers or gives example of the same concept is codified under the same name. A closed codification guided by concepts (also known as of closed kind) was done, defined by Gibbs as "an analysis in which the researcher is encouraged to develop a list of key theme ideas before assigning codes to the text. These thematic ideas can be taken from earlier publications and studies, but most are generated by reviewing at least some of the transcriptions and other documents, such as field notes, discussion groups and other written documents. In this case, thematic ideas were taken from the concepts set out on the EduCamp experience reported by Leal, a link with the digital native and immigrant proposed by Prensky, and a contrast with the results obtained on the studies realised by Kennedy et al and Kvavik et al. In table number 1 , the used codes can be seen, along with their corresponding definition: 
Table 1. Proposed codes and definitions

\begin{tabular}{|c|c|}
\hline Code & Definition \\
\hline Hardware & $\begin{array}{c}\text { Physical components of an } \\
\text { informatics device. }\end{array}$ \\
Software & $\begin{array}{c}\text { Computer program designed to } \\
\text { elaborate specific actions. }\end{array}$ \\
\hline Web 2.0 Tools & $\begin{array}{c}\text { Non-static Web sites which } \\
\text { allow the creation of content by } \\
\text { the users. }\end{array}$ \\
\hline $\begin{array}{c}\text { Virtual Social } \\
\text { Networks }\end{array}$ & $\begin{array}{c}\text { Online social communication } \\
\text { media for the exchange of } \\
\text { personal profiles. }\end{array}$ \\
\hline $\begin{array}{c}\text { Personal } \\
\text { Learning }\end{array}$ & $\begin{array}{c}\text { Self-learning management } \\
\text { system focused on objectives. }\end{array}$ \\
\hline $\begin{array}{c}\text { Cooperative } \\
\text { Learning }\end{array}$ & $\begin{array}{c}\text { Educational approach with base } \\
\text { on social experiences. }\end{array}$ \\
\hline
\end{tabular}

\subsection{Results}

In table number 2, results of the codification of the online survey collected data are shown:

Table 2. Codification of online survey data

\begin{tabular}{|c|l|}
\hline Code & \multicolumn{1}{|c|}{ Data } \\
\hline Hardware & \multicolumn{1}{|c|}{ None } \\
\hline Software & $\begin{array}{l}\text { "programs that are useful for } \\
\text { developing diverse skills", } \\
\text { "programs that focus on video } \\
\text { filming and editing, as well as } \\
\text { programs for the creation of } \\
\text { infographics", "having already } \\
\text { installed the programs that are } \\
\text { going to be used by the students", }\end{array}$ \\
\hline Web 2.0 Tools & $\begin{array}{l}\text { "digital tools, such as instagram, } \\
\text { gmail and googledrive", "prezii } \\
\text { and wordpress", "using frequently } \\
\text { google drive", "zotero... the } \\
\text { ERIC tool", "drop box and } \\
\text { zotero", }\end{array}$ \\
Virtual Social & $\begin{array}{l}\text { "I learned how to use other webs, } \\
\text { tools and platforms", "to create } \\
\text { the corresponding accounts for the } \\
\text { applications and tools" }\end{array}$ \\
\hline Networks
\end{tabular}

\begin{tabular}{|c|l|}
\hline Code & \multicolumn{1}{|c|}{ Data } \\
\hline $\begin{array}{c}\text { Personal } \\
\text { Envirning }\end{array}$ & $\begin{array}{l}\text { "both my professional and } \\
\text { personal development", "web } \\
\text { tools that were interesting to me", } \\
\text { "reinforce these skills in school or } \\
\text { the job I choose" }\end{array}$ \\
\hline $\begin{array}{c}\text { Cooperative } \\
\text { Learning }\end{array}$ & $\begin{array}{l}\text { "Inform of these new programs to } \\
\text { people who do not know about } \\
\text { them". "together we reinforced } \\
\text { our knowledge", "new tools that I } \\
\text { learned with help from from the } \\
\text { other students", "it was very } \\
\text { interesting to be able to share } \\
\text { what we know and our doubts and } \\
\text { experiences" }\end{array}$ \\
\hline
\end{tabular}

It can observed that none of the participants mentioned to have learned to use aspects related to the equipment Hardware, from which it can be inferred that the use of physical parts (connecting peripherals, turning on the machine, etc.) is a common skill between both digital natives and immigrants., this reinforced by the observation done during the workshop, in which no problem related to this aspect was detected. On the issue of Software, participants showed affinity towards learning to use multimedia tools, from which very few participants affirmed having knowledge of, this in addition to many cases in which this tools could not be explained by those who had knowledge of them, because they are programs that were not installed on the assigned computers.

About Web 2.0 Tools, it could be observed a great variety of knowledge between the participants, with the bibliographical quoting tool Zotero being one of the most sought after by the participants; some of them commented that it interested them specially to learn that tool because it would be of great utility when writing their end of course essays, in some cases there could be seen five or six students around the same computer paying close attention to the explanation of an expert on this tool. Other popular tools were the Google Drive and Drop Box services, which for some people was their first approach to Cloud Computing file sharing technologies, a term that was initially confusing for some of the participants, who did not know what it truly referred to, but had heard in communication media as the most important emerging technology. An important observation was that, in general, the Master in Educational Research students, considered digital immigrants, presented a greater knowledge of these technologies, it can be inferred from their comments that they found themselves in the necessity of learning to use them in order to take care 
of their job activities in more effective ways, a situation students from the Degree in Education have not yet faced due to being several years younger.

Virtual Social Networks were mostly discussed by the grade students, especially those entered on multimedia files sharing, such as photographs, videos, music, books, etc., while the post-grade students showed more interest on LinkedIn, a professional contacts site which lets users create a virtual curriculum vitae that can be shared directly with possible employers. This discrepancy can be related to the fact that the younger students have more free time, and thus spend a bigger part of it in leisure activities, while the older students gave priority to those sites that could be of use for their professional development. While the specific concept of Personal Learning Environment, was new to both student groups (digital natives and immigrants), it appeared under other names in their comments, as they mentioned focusing on learning those tools they thought would be more useful to them or were of personal interest, as well as those which would improve their academic or professional activities; it can be seen that both groups pointed out the importance of these tools for both areas, despite being told to focus only on those they found personally interesting.

Finally, it was observed that students responded positively to the activity, commenting that working with their peers was effective for their learning of new digital tools, however, during the observation process it was detected that not all of them participated in the same manner: while the instruction given by the researcher was to work in pairs, learn the tool, and then change partners, many of the participants, especially in the case of women, formed small groups of two or three persons who asked together to be taught how to use some tool at the same time, with some cases ending up in six people working around the same computer. It can be inferred by triangulating this observation with the answers given on the survey, that some of the participants, especially those in the grade group, due to having little confidence on their digital skills, found security in working inside teams on which they could ask more basic questions without needing to interrupt the currently explaining person, and thus avoid to end up being seen as less skilled; these same persons, generally, spent their time learning new tools one after another, maybe seeking to avoid having to take the role of explaining a tool to another student; also, they pointed out in their survey answers that they would have liked to have more time for taking notes of the explanations.

\section{Conclusions}

Analysis of the data provided by the survey, as well as the observation of student behavior during the workshop, permitted the identification of many relevant issues for the study, especially those related with the differences between both groups derived from their condition as digital natives or immigrants.

A particularly interesting result was that, in general, the digital immigrants knew more tools focused on the professional area than the digital natives, as a result of their job demands, while the younger students showed more knowledge of Virtual Social Networks for the sharing of entertainment material (photographs, videos, music, etc.), which excite them visibly. This in contrast to what is presented on the consulted literature, where it was expected for the younger generations to be more fluent on these technologies than their elders; on the same issue, it was observed that the Master Degree students showed more security while explaining how to use these tools to their peers, along with asking more questions when learning a new tool and trying to compare it with others they already knew, this can be related to their higher grade of development and maturity acquired as a result of their professional job time, an environment that many of the digital natives have not yet confronted.

However, it could also be observed that the Grade Degree students show a great motivation towards learning these tools, tailoring them to their needs, and as was observed in one case, transfer the abilities they acquired during their leisure time towards other areas. In general, it can be concluded that the experience of taking part on this workshop was positive for both groups, fulfilling its objective, in addition to providing useful information for its improvement, especially in the case of time management for the activities and clarity of the instructions, which could be used in the case of a future replication.

\section{References}

[1] Prensky, M. "Digital natives, digital immigrants", On The Horizon, 9 (5), 2001, pp. 1-2. Recovered from http://www.marcprensky.com/writing/Prensky\%2020Digital\%20Natives, \%20Digital\%20Immigrants\%20$\% 20$ Part1.pdf (Access date: 20 September, 2014).

[2] Kennedy, G., Krause, K., Judd, T.,Churchward, A. and Gray, K. “First year student's experience with technology: are they really digital natives?". 2006. Recovered from https://www.griffith.edu.au/_data/assets/pdf_file/0008/39 266/NativesReport.pdf (Access date: 20 September, 2014).

[3] Kvavik, R., Caruso, J. and Morgan, G. "ECAR study of students and information technology 2004: convenience, connection, and control", British Journal of Education Technology, 39 (5), 2004. Recovered from https://net.educause.edu/ir/library/pdf/ers0405/rs/ers0405w .pdf (Access date: 20 September, 2014).

[4] Vidal, M., Vialart, M. y Hernández, L. “Redes sociales: Social networks", Educación Medica Superior, 27(1), 
2013, pp. 146-157. Recovered from http://scielo.sld.cu/scielo.php?script=sci_arttext\&pid=S086 4-21412013000100017\&lang=pt (Access date: 20 September, 2014).

[5] Parra, E. "Las redes sociales de Internet:también dentro de los hábitos de los estudiantes universitarios", Anagramas, 9 (17), 2010, pp.107-116. Recovered from http://www.scielo.org.co/scielo.php?script=sci_arttext\&pid $=$ S1692-25222010000200009\&lang=pt (Access date: 20 September, 2014).

[6] Santana, S. "Redes de intercambio de información científica y académica entre los profesionales en el contexto de la Web 2.0", ACIMED, Revista Cubana de los Profesionales de la Información y la Comunicación en Salud, 21 (3), 2010. pp. 321-333. Recovered from http://scielo.sld.cu/scielo.php?script=sci_arttext\&pid=S102 4-94352010000300006\&lang=pt

[7] Abarca, S. "Las redes sociales como instrumento de mediación pedagógica: alcances y limitaciones", Revista de Actualidades Investigativas en Educación, 13(2), 2013, pp. 1-18. Recovered from http://www.scielo.sa.cr/scielo.php?script=sci_arttext\&pid= S1409-47032013000200013\&lang=pt (Access date: 20 September, 2014).

[8] Torre, A. "Nuevos perfiles en el alumnado: la creatividad en nativos digitales competentes y expertos rutinarios", Revista de Universidad y Sociedad del Conocimiento, 6 (1), 2009, pp. 7-14. Recovered from http://www.redalyc.org/articulo.oa?id=78011179008 (Access date: 20 September, 2014).

[9] Piscitelli, A., Adaime, I. and Binder, I. "El proyecto Facebook y la pos-universidad: sistemas operativos sociales y entornos abiertos de aprendizaje". Telefónica, España, 2010, pp. 15. (Access date: 20 September, 2014).

[10] Alarcón, M. and Lorenzo, C. "Diferencias entre usuarios y no usuarios de redes sociales virtuales en la Web 2.0", Enl@ce: Revista Venezolana de Información, Tecnología y Conocimiento, 9 (2), 2012, pp. 31-49. Recovered from http://www.redalyc.org/articulo.oa?id=82323417003

[11] Lorenzo-Romero, C., Gómez-Borja, M. and Alarcóndel-Amo, M. "Redes sociales virtuales, ¿de qué depende su uso en Europa?", Innovar, Revista de Ciencias Administrativas y Sociales, 21 (41), 2011, pp. 145-157. Recovered from http://www.redalyc.org/articulo.oa?id=81822806011

[12] Pineda, E., Meneses, T. y Téllez, F. “Análisis de redes sociales y comunidades virtuales de aprendizaje: antecedentes y perspectivas", Revista Virtual Universidad Católica del Norte, 38, 2013, pp. 40-55. Recovered from http://www.redalyc.org/articulo.oa?id=194225730004

[13] Torres-Díaz, J., Dunia, I. y Valdiviezo, P. "Integración de redes sociales y entornos virtuales de aprendizaje”, RED, Revista de Educación a Distancia, 35, 2013, pp. 1-8. Recovered from http://www.redalyc.org/articulo.oa?id=54725583004
[14] Duart, J. "Internet, redes sociales y educación", RU\&SC: Revista de Universidad y Sociedad del Conocimiento, 6 (1), 2009. Recovered from http://www.redalyc.org/articulo.oa?id=78011179001

[15] Martínez, R., Corzana, F. y Millán, J. "Experimentando con las redes sociales en la enseñanza universitaria en ciencias", Revista Eureka sobre Enseñanza y Divulgación de las Ciencias, 10 (3), 2013, pp. 394-405. Recovered from http://www.redalyc.org/articulo.oa?id=92028240006

[16] Stornaiuolo, A., Dizio, J, y Hellmich, E. "Desarrollando la comunidad: jóvenes, redes sociales y escuelas", Comunicar, 20 (40), 2013. Recovered from http://www.redalyc.org/articulo.oa? $\mathrm{id}=15825476010$

[17] Aguilar, D., Said, E. "Identidad y subjetividad en las redes sociales virtuales: caso de Facebook", Zona Próxima, 12, 2010, pp. 190-207. Recovered from http://www.redalyc.org/articulo.oa?id=85316155013

[18] Esquivel, A. "Uso y función de los recursos educativos abiertos y las tecnologías móviles para la formación inicial docente". Universidad Autónoma de Yucatán: México, 2012.

[19] Gómez, M., Roses, S. y Farías, P. "El uso académico de las redes sociales en universitarios", Comunicar, 19 (38), 2012, pp. 131-138. Recovered from http://www.redalyc.org/articulo.oa?id=15823083016

[20] Gibbs, G. "El análisis de datos cualitativos en investigación cualitativa". Ediciones Morata: Madrid, 2012. 